ФАСИЛІТУЮЧА ДІАЛОГІЧНА КОМУНІКАЦІЯ У СІМ'ЯХ ВЧИТЕЛІВ ПОЧАТКОВОЇ ШКОЛИ

\title{
FACILITATING DIALOGUE COMMUNICATION IN FAMILIES OF PRIMARY SCHOOL TEACHERS
}

у статті висвітлено сутність понять «сім'я», «фрасилітація», «діалогічна комунікація», «фрасилітуюча діалогічна комунікація». Наведено значення фрасилітації у сімейних взаєминах вчителів початкової школи. Сорормовано модель фрасилітуючих сімейних взаємин. Виокремлено, що найбільше значення для формування особистості має морально-психологічний клімат у сім'ї, який визначає та опосередковує всі інші фрактори. Сам мікроклімат сім'ї залежить від характеру сімейних взаємин, перш за все подружніх і дитячо-батьківських. Окреслено фрактори й прояви фрасилітації в сім'ї. Наголошено на тому, що результатом фрасилітуючого впливу батьків буде гармонізація сімейних взаємин, повноцінне фуункціонування сім'і, сприятлива психологічна атмоссрера, психологічне здоров'я членів сім'ї, розвиток $і$ самоактуалізація особистості в сімї. Визначено головну орієнтацію принципу фрасилітації у сім'ях вчителів початкової школи, а саме опору на потениійні можливості педагога в самоактуалізації, універсальною характеристикою якої $є$ креативність «фундаментальна характеристика людської природи», «потенція, надана кожній людині від народження», «спосіб світосприйняття, взаємодії з реальністю». Розглянуто одну з фрасилітуючих функцій сім'і, а саме комунікативну. Зазначено три умови, за яких формується середовище фрасилітуючої діа логічної комунікації, таких як справжність, щирість або конгруентність (переживання своїх власних почуттів, їх відкритість собі та партнеру); прийняття, піклування чи визнання; емпатичне розуміння (подружжя сприймає почуття, емоції, пережиті один одним, та комуніцує це сприйняте розуміння один одному). Доведено необхідність впровадження терміна «фрасилітуюча діалогічна комунікація» у сім'ях учителів початковоі школи задля вирішення сімейних проблем, особистісного розвитку загалом, що сприяє плідній співпраці педагога з учнями в умовах Нової української школи, прийняттю та постійній підтримиі учнів, взаємоповазі та довірі. Зроблено висновок, що в умовах діалогічної комунікації фрасилітація набуває особливого змісту та розглядається як показник розвитку сімейних взаємин і самоактуалізації вчителя початкової школи.

Ключові слова: сім'я, сімейні взаємини, подружні взаємини, дитячо-батьківські взаємини, фрасилітація, срасилітуюча діалогічна комунікація.
The article highlights the essence of the concepts "family", "facilitation" "dialogic communication", and "facilitating dialogic communication". The importance of facilitation in the family relationships of primary school teachers is given. A model of facilitating family relationships has been formed. It is emphasized that the most important for the formation of personality is the moral and psychological climate in the family, which determines and mediates all other factors. In turn, the microclimate of the family depends on the nature of family relationships, especially marital and child-parent. Factors and manifestations of facilitation in the family are outlined. It is emphasized that the result of the facilitating influence of parents will be the harmonization of family relationships, the full functioning of the family, a favorable psychological atmosphere, the psychological health of family members, the development and self-actualization of the individual in the family. The main orientation of the principle of facilitation in the families of primary school teachers is determined - reliance on the potential of the teacher in self-actualization, the universal characteristic of which is creativity - fundamental characteristics of human nature, potential given to everyone from birth, way of worldview reality. One of the facilitating functions of the family - communicative - Is considered. There are three conditions under which the environment of facilitating dialogic communication is formed: authenticity, sincerity or congruence (experiencing one's own feelings, about their openness to oneself and one's partner); acceptance, care or recognition; empathic understanding (spouses perceive feelings, emotions experienced by each other, and communicate this perceived understanding to each other). The necessity of introducing the term "facilitating dialogic communication" in the families of primary school teachers in order to solve family problems, personal development in general, which promotes fruitful cooperation of teachers with students in the New Ukrainian school, acceptance and constant support of students, mutual respect and trust. It is concluded that in the conditions of dialogic communication facilitation acquires a special meaning and is considered as an indicator of the development of family relations and self-actualization of the primary school teacher.

Key words: family, family relations, marital relations, child-parent relations, facilitation, facilitating dialogic communication.
Постановка проблеми. Сімейні взаємини у вітчизняній психології на сучасному етапі потребують постійного наукового вивчення, яке допомагає, по-перше, розуміти реально наявні процеси внутрішньо-сімейної життєдіяльності та численні зовнішні зв'язки сім'ї; по-друге, прогнозувати їх розвиток, врахову- ючи досвід, надавати за необхідності адекватну допомогу сім'ї, координувати ії взаємодію з іншими соціальними структурами держави. Безумовно, зміцнення сімейних взаємин багато в чому залежить від їх соціально-економічної, правової захищеності. Водночас причини більшості сімейних проблем часто кри- 
ються або в особливостях сімейної комунікації, або в індивідуальних характеристиках членів сім'ї, тобто мають психологічний характер.

Важливою для нашого дослідження $€$ ідея О. Гарджі, згідно з якою у людей є глибока потреба спілкуватися, і чим більше таких можливостей щодо цього, тим задоволеніше та корисніше буде їхнє життя. Внесок кваліфікованої міжособистісної комунікації в успіх як в особистому, так і в професійному контексті нині широко визнаний і ретельно досліджений. Таким чином, знання різних типів навичок та їх впливу на соціальну взаємодію має вирішальне значення для ефективного міжособистісного функціонування [11].

Вчитель початкової школи як учасник діалогу, діючи в комунікативно-орієнтованому середовищі, досягає необхідних освітніх результатів, слідуючи своєю індивідуальною освітньою траєкторією. В результаті цього відбувається формування власного освітнього середовища, в якому використовуються можливості комунікативно-діалогових технологій у процесі самоосвіти та саморозвитку.

Аналіз останніх досліджень і публікацій. Так, серед безлічі факторів, що визначають гармонійність сім'ї та задоволеність шлюбом, науковому аналізу все частіше піддаються особливості сімейної комунікації (Ю. Альошина, А. Антонов, А. Бодальов, К. Вітек, Л. Гозман, С. Голод, А. Кронік, Н. Обозов, В. Сатир).

Постановка завдання. Метою статті $€$ розгляд фасилітуючої діалогічної комунікації в сім'ях учителів початкової школи.

Виклад основного матеріалу дослідження. Протягом кількох десятиліть у вітчизняній психології сім'я розглядається, по-перше, як соціальний інститут, по-друге, як мала група. Сім'я вивчається з двох позицій, а саме її зовнішньої структури (взаємодії з іншими соціальними інститутами й суспільством загалом) та внутрішньої (виконання своїх функцій, сімейних ролей). Початок такого підходу до вивчення сім'ї було покладено відомим соціологом А. Харчевим, підґрунтям концепції якого було вивчення функцій сім'ї, які покликані реалізувати можливості сім'ї як мети (створення оптимальних умов для соціалізації дітей), так і засобів задоволення суспільних, групових та індивідуальних потреб. Через свої функції сім'я пов'язана, з одного боку, із суспільством, з іншого боку, з індивідами, які увійшли до її складу. 3 точки зору вченого, сім'я виконує такі функції, як репродуктивна (дітонародження), сексуальна (регулювання сексуальної поведінки), інтимна (емоційна стабілізація індивідів, організація раціонального дозвілля), економічна (матеріальне утримання дітей та непрацездатних членів сім'ї), соціальна (виховання дітей, адаптація молодого покоління в соціумі), статусна (надання певного соціального статусу членам сім'ї, відтворення соціальної структури) [8].

Відзначимо, що процес гармонійної взаємодії у сім'ях учителів початкової школи відбувається за принципом фасилітації. Принцип фасилітації - це теоретико-методологічна складова частина створення умов для усвідомлення підтримуваними глибоко індивідуальної сутності, самостійності та становлення автором і творцем життєвих обставин [2] .

Понятійній апарат, зміст та структура феномена «фасилітація», визначення властивостей суб'єктів процесу, дослідження особливостей фасилітуючого впливу розглянуто у працях В. Абрамова, І. Авдєєвої, О. Андрєєва, А. Болотової, О. Врубльовської, О. Дімової, О. Кондрашихіної, О. Левченко, П. Лушина, Г. Межиної, Л. Петровської.

Вперше ефект фасилітації - поліпшення індивідуального результату за рахунок присутності іншої людини - був виявлений у дослідженнях Н. Триплета. Першим став вживати термін «фасилітація» в новому контексті Г. Олпорт у 1920 році, використовуючи таке трактування: фасилітація - це зміна поведінки людини в результаті присутності інших людей, що виконують туж роботу в той же час, але незалежно один від одного. На нашу думку, фасилітація - це особистісно-орієнтований підхід, що виражається у глобальній довірі до людини, відображає наявну актуалізуючу тенденцію зростати, розвиватися, реалізовувати свій потенціал. В результаті дослідження сімейних взаємин термін «фасилітація» можна визначити як процес позитивного впливу подружжя на свідомість і поведінку один одного, внаслідок якого підвищується продуктивність розумової діяльності, активізуються позитивні емоції і почуття, які проявляються в моральних вчинках.

Факторами і проявами фасилітації в сім'ї $\epsilon$ відкритість партнеру, підтримка та захищеність у взаєминах, рівень задоволення особистісних потреб та потреб партнера, взаємна емпатія, особистісна зрілість батьків і гуманістичні установки, адекватні батьківські позиції і довірчі відносини з дитиною, позитивні батьківські почуття, дієва батьківська любов і прихильність, турбота, емоційна ідентифікація із сім'єю. Мають значення адекватний рівень задоволення потреб дитини, заборон, вимог і санкцій, стійкий стиль сімейного виховання й батьківська відповідальність.

Важливо відзначити, що результатом фасилітуючого впливу батьків буде гармонізація сімейних взаємин, повноцінне функціонування сім'ї, сприятлива психологічна атмосфера, психологічне здоров'я членів сім'ї, розвиток і самоактуалізація особистості в сім'ї (рис. 1).

З огляду на рис. 1 роль сім'їв житті подружжя та дитини важко переоцінити. Сім'я закладає всю систему ціннісних орієнтирів, взаємин 
з оточуючими, способи й форми діяльності. На думку Л. Виготського, в батьківській родині закладаються основи формування вищої психічної діяльності дитини.

Сім'я може бути як потужним фактором розвитку та емоційно-психологічної підтримки особистості, так і джерелом психічної травми людини й пов'язаними з нею різноманітними особистісними розладами, зокрема неврозами, психозами, психосоматичними захворюваннями, сексуальними перверсіями та відхиленнями в поведінці.
До сімейної атмосфери, її стану, перспектив людина чутлива протягом усього свого життя. Однак найбільший вплив сім'я здійснює на формування особистості. У сім'ї зароджується ставлення дитини до самої себе та оточуючих ії̈ людей. У ній відбувається первинна соціалізація особистості, освоюються перші соціальні ролі, закладаються основні цінності життя.

Батьки природним чином впливають на своїх дітей через механізми наслідування, ідентифікації та інтеріоризації зразків батьківської поведінки. Сімейне виховання має як уні-

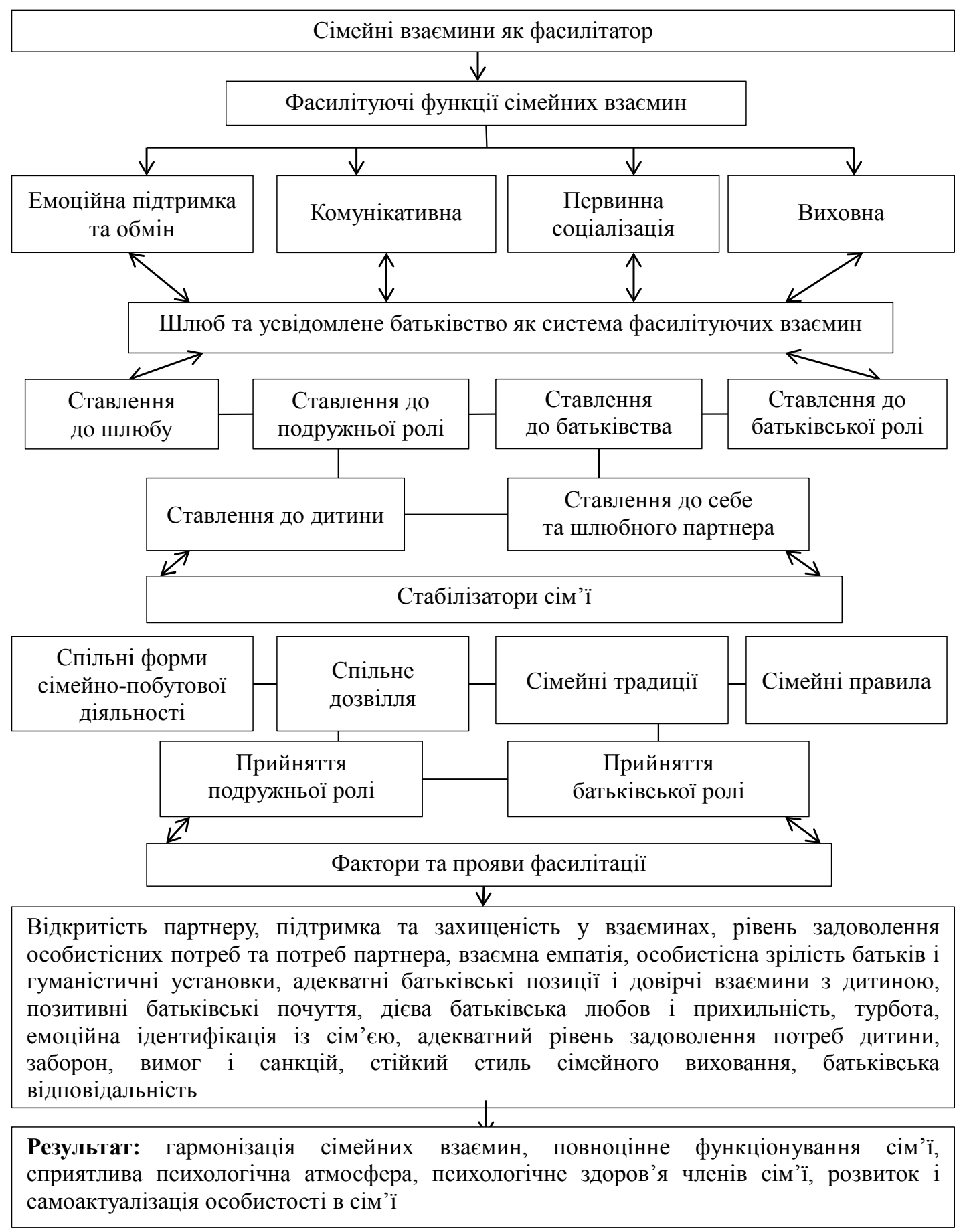

Рис. 1. Модель сімейних взаємин як фасилітатора 
кальний каталізатор родинні почуття. Сімейне виховання індивідуальне, тому незамінне ніякими сурогатами анонімного виховання. Його відсутність або вади важко компенсувати в подальшому житті людини.

На думку фахівців, найбільше значення для формування особистості має морально-психологічний клімат у сім'ї, який визначає та опосередковує всі інші фактори. Сам мікроклімат сім'ї залежить від характеру сімейних взаємин, перш за все подружніх і дитячо-батьківських [6; 9].

На нашу думку, виховний потенціал сім'ї визначається через дитячо-батьківські взаємини.Сім'язвисокимвиховнимпотенціалом-це сім'я, в якій вона й батьківство є термінальними життєвими цінностями, де присутнє безумовне прийняття дитини як особистості, позитивне ставлення дитини до батька (матері) й батьків як сімейного подружжя, не порушено структуру сімейних зв'язків і функціонально-рольову взаємодію, переважають соціально бажаний тип поведінки батьків і соціальна адекватність поведінки дітей. Сім'ї з низьким виховним потенціалом мають протилежні характеристики [6].

Зауважимо, що головна орієнтація принципу фасилітації у сім'ях вчителів початкової школи - це опора на потенційні можливості педагога в самоактуалізації, універсальною характеристикою якої є креативність - «фундаментальна характеристика людської природи», «потенція, надана кожній людині від народження», «спосіб світосприйняття, взаємодії з реальністю» [7, с. 68].

Сутність фасилітації полягає в тому, щоб актуалізувати креативність педагога, щоб він у все привносив властиве тільки йому ставлення до цих подій, щоб кожен його акт ставав актом творчості, був тим, ким він може бути, відповідав своїй природі. Задоволення потреби в самоактуалізації в цьому разі є превентивним заходом профілактики фрустрації.

Рушійною силою здорової людини є необхідність у розвитку та повній актуалізації закладених у ній потреб. Головне, що буде відрізняти самоактуалізованого вчителя початкової школи від середньостатистичного, - це не кількісні, а якісні відмінності, тобто його бажання не вступають у конфлікт із розумом, актуалізовано власну «самість», власне «Я», яке завжди унікальне й неповторне, він відповідально виконує свій професійний і громадянський обов'язок.

Так, однією з фасилітуючих функцій сім'ї єкомунікативна. Вонапов'язана іззадоволенням потреби сім'ї у спільному проведенні часу, взаємному культурному та духовному збагаченні. Вона сприяє духовному розвитку членів сім'ї. Ступінь розвиненості комунікації в сім'ї відповідає ступеню розвиненості комунікації в суспільстві. Позитивна й ефективна сімейна комунікація сприяє особистісному зростанню членів сім'ї.

Сімейна комунікація розглядається у психології як сукупність характеристик, що визна- чають особливості регулювання суб'єктом своєї діяльності й поведінки. Найважливішими характеристиками сімейної комунікації та її складових частин є взаєморозуміння, довірливість, легкість спілкування, психотерапевтичність, наявність загальних символів сім'ї [1; 4]. Сутність психотерапевтичної комунікації часто описується через емоційний контакт або емпатію партнерів. Е. Карлін виділяє самоактуалізуюче спілкування. Це відкрите довірче спілкування, засноване на адекватному вираженні власних почуттів і повазі партнера, щирій зацікавленості в ньому, безумовному прийнятті, повазі, щирості, уважності, доброзичливості, включенні в ситуацію. Ознаками психотерапевтичної комунікації $€$ наявність у партнерів почуття безпеки, любові та прихильності, гармонії у взаєминах, відчуття поваги, схвалення, визнання компетентності, наявність можливості актуалізації своїх здібностей, досягнення власних цілей [3, с. 22].

На основі досліджень представників інтеракціонізму (Г. Блумер, Т. Шибутані) І. Цимбалюк визначає, що діалогічна комунікація ґрунтується на спроможності людини «перебирати роль іншого» та уявляти, як це сприймає партнер по спілкуванню, група чи значуща людина, а також інтерпретувати певну ситуацію та конструювати власні дії [9].

Інший підхід до цієї проблеми висвітлюється представниками комунікативної школи. Так, модель Мак-Мастера включає дві такі найважливіші характеристики комунікативних процесів у сім'ї: відкритість чи замаскованість інформації, якою обмінюються члени сім'ї; те, наскільки така інформація висловлюється прямо чи опосередковано [10].

Підтримуючи представників інтеракціонізму (Г. Блумера, Т. Шибутані та І. Цимбалюк), ми вважаємо, що діалогічна комунікація має на меті не лише обмін інформацією, узгодження зусиль і «перебирання ролей» у спільній діяльності, установлення та розвиток міжособистісних відносин, але й розвиток навичок слухання, стилів реагування та здібностей говоріння під час формування сімейних взаємин учителів початкової школи в результаті формування підростаючої особистості, задоволення потреб у належності, прийнятті та любові, розвиток потреби в спілкуванні, становлення їі духовного й морального компонентів.

Отже, по-перше, якісна сімейна комунікація забезпечує вирішення проблем подружньої сумісності, конфліктності, дитячо-батьківських взаємин, професійного саморозвитку. Задоволеність шлюбом - це результат реальних вкладень людини в забезпечення сімейної гармонії. По-друге, застосування фасилітаційного підходу у педагогічній діяльності в умовах Нової української школи передбачає створення на заняттях середовища, оптимального для вирішення освітнього завдання на основі 
співпраці педагога з учнями, прийняття та постійної підтримки учнів, віри в їх здібності, взаємоповаги та довіри. Фасилітаційний підхід сприяє розвитку активної особистісної позиції, найбільш повного задоволення пізнавальних і творчих потреб, отже, самоактуалізації учнів. Таким чином, організація навчання у фасилітаційному режимі, тобто у полегшенні, сприянні, стимулюванні, активізації розвитку учнів, обов'язково пов'язана з наданням їм більшої свободи й відповідальності, загальною гуманізацією міжособистісного спілкування в школі.

Існує три умови, за яких формується середовище фасилітуючої діалогічної комунікації. Насправді ці умови застосовуються в будьякій ситуації, де метою є розвиток особистості. Подібно до того, як у психології успішне втілення цих установок приводить до становлення та зміцнення людського плану міжособистісного спілкування психолога та клієнта, подібний комунікативний план формується в сімейних взаєминах між подружжям. Такими елементами фасилітуючої діалогічної комунікації є справжність, щирість або конгруентність (одна з трьох необхідних і достатніх умов ефективного контакту і взаємин, розроблених у рамках особистісно-орієнтованого підходу). Якщо під час емпатії йдеться про співпереживання емоційному стану подружнього партнера, то за конгруентності - про переживання власних почуттів, їх відкритість собі та партнеру [5, с. 190].

Другою умовою $є$ прийняття, піклування чи визнання, тобто безумовне позитивне прийняття. Коли партнер відчуває позитивну установку по відношенню до іншого і приймає його цілісно, а не обумовлено, тоді подальший особистісний розвиток кожного 3 них більш імовірний.

Третя умова - це емпатичне розуміння. Це означає, що подружжя сприймає почуття, емоції, пережиті один одним, та комуніцує це сприйняте розумінняодинодному. В результаті цього емоційне ставлення до партнера по спілкуванню виражає рівень задоволеності ним.

Отже, ми вважаємо, що запровадження терміна «фасилітуюча діалогічна комунікація» $€$ виправданим, оскільки вирішення конфліктності у сім'ях можливе лише в результаті спілкування подружніх партнерів, тобто побудови конструктивного діалогу на основі істинності й відкритості, прийняття і довіри, емпатичного розуміння, що сприяє плідній співпраці педагога з учнями в умовах Нової української школи, прийняттю та постійній підтримці учнів, взаємоповазі та довірі.

Оптимізація діяльності одного партнера за активної підтримуючої присутності іншого визначається рівнем фасилітації. Чим вище здатність вчителів початкової школи до фасилітуючої діалогічної комунікації у вирішенні сімейних проблем, тим більш індивідуалізований, диференційований і творчий підхід до учнів, тим більше уваги вони приділяють переживанням учнів, частіше вступають з ними в діалоги, частіше співпрацюють з ними під час планування навчального процесу, використовують їх пропозиції в роботі, тобто шлюбні партнери, які розуміють і приймають внутрішній світ один одного без будь-яких оцінок, поводяться природно, згідно зі своїми внутрішніми переживаннями, нарешті, доброзичливо та з підтримкою ставляться один до одного, створюють необхідні умови для фасилітації їх особистісного розвитку загалом. В результаті цього важливістю для самого вчителя початкової школи стає формування фасилітативних якостей, які виступають як спосіб збереження й підвищення його професійної компетентності, що позитивно впливає на особистісний розвиток його учнів.

Висновки 3 проведеного дослідження. Отже, в умовах діалогічної комунікації фасилітація набуває особливого змісту та розглядається як показник розвитку сімейних взаємин і самоактуалізації вчителя початкової школи, тому ми вважаємо за необхідне впровадження терміна «фасилітуюча діалогічна комунікація». Перспективами подальшого дослідження визначено пошук практичних механізмів (форм, методів, прийомів та засобів) щодо впровадження фасилітації у сім'ях вчителів та в умовах Нової української школи.

\section{ЛITЕРАТУРА:}

1. Вельская О. Факторы благополучия семьи: удовлетворенность браком, сплоченность, гибкость. Вестник УРАО. 2017. № 3. С. 57-61.

2. Жижина И. Психологические особенности развития фрасилитации педагога : дисс. ... канд. психол. наук : спец. 19.00.07. Екатеринбург, 2000. 153 с.

3. Карлин Е. Психотерапия как особая фрорма общения. Журнал практической психологии и психоанализа. 2014. № 3. С. 20-25.

4. Крамар Е. Категория общения как фрактор развития личностного и семейного потенциала супруга в структуре семейных взаимоотношений. Ученые записки Крымского инженерно-педагогического университета. 2017. № 2. C. 84-89.

5. Максимова Н. Психологічні критерії екологічності сімейних стосунків. Актуальні проблеми психології : збірник наукових праць. Вип. 45. Житомир : вид-во ждУ ім. І. Франка, 2018. С. 188-196.

6. Овчарова Р. Психолого-педагогическая фрасилитация профессиональной деятельности учителя : учебное пособие. Курган : изд-во Курганского государственного университета, 2016. 210 с.

7. Роджерс К., Фрейберг Д. Свобода учиться. Москва : Смысл, 2002. 527 с.

8. Харчев А. Современная семья и ее проблемы : социально-демографическое исследование. Ереван : Айастан, 1982. 271 с.

9. Цимбалюк І. Психологія спілкування : навчальний посібник. Київ : Профресіонал, 2004. 303 с.

10. Эйдемиллер Э., Юстицкис В. Психология и психотерапия семьи. 4-е изд. Санкт-Петербург : Питер, 2009. 672 с.

11. Hargie O. Skilled interpersonal communication: Research, theory and practice. London, 2016. 658 p. 